\section{Case Reports in Dermatology}

Case Rep Dermatol 2016;8:294-302

DOI: $10.1159 / 000452326$

Publisned onIIne: November 14, 2016

(c) 2016 The Author(s)

Published by S. Karger AG, Basel

www.karger.com/cde

This article is licensed under the Creative Commons Attribution-NonCommercial 4.0

International License (CC BY-NC) (http://www.karger.com/Services/OpenAccessLicense).

Usage and distribution for commercial purposes requires written permission.

\title{
A Rare Case of Mycosis Fungoides in the Oral Cavity and Small Intestine Complicated by Perforation
}

\author{
Drew Arthur Emge $^{a} \quad$ Juri Bassuner ${ }^{b}$ Daniel J. Lewis ${ }^{a, b}$ \\ Madeleine Duvic ${ }^{b}$ \\ ${ }^{a}$ Baylor College of Medicine, Houston, TX, USA; ${ }^{b}$ The University of Texas MD Anderson \\ Cancer Center, Houston, TX, USA
}

\section{Keywords}

Mycosis fungoides · T-cell lymphoma · Non-Hodgkin lymphoma · Gastrointestinal · Small intestine - Oral cavity

\begin{abstract}
Extracutaneous involvement in mycosis fungoides (MF) carries a poor prognosis. Oral and gastrointestinal (GI) tract lesions are both rare locations of disease. We describe the clinical findings of one case with oral and GI MF complicated by perforation after systemic antineoplastic treatment, and review the relevant literature. The patient had a 1-year history of MF before development of tongue and palate tumors. He was treated with local electron beam radiation, but re-presented to the hospital after what was found to be small intestine perforation following systemic antineoplastic therapy. The case reveals key insights into the progression and complications of lymphomas with GI tract involvement.
\end{abstract}




\section{Introduction}

Mycosis fungoides (MF) is a cutaneous, extranodal, insidious non-Hodgkin T-cell lymphoma $[1,2]$. Almost any location in the body can be infiltrated by MF, including the oral cavity and the gastrointestinal (GI) tract [3].

Oral cavity and GI involvement of MF are rare as separate entities [3-5]. Individuals with extracutaneous lesions have a poor prognosis. We present one case of MF with both oral and visceral involvement, with complication of intestine perforation after treatment.

\section{Case Report}

A 38-year-old man with congenital ichthyosis and presumed psoriasis presented in late 2015 with erythroderma, numerous plaques, and tumors affecting his body and face. His skin was generally denuded and ulcerated on the arms and trunk. The lesions were weeping serous fluid.

He was admitted for methicillin-resistant Staphylococcus aureus skin infection and treated with whirlpool therapy and intravenous antibiotics. Initial histology was consistent with psoriasiform epidermal hyperplasia with spongiosis. Although the biopsy showed exocytosis and lymphocytes, there was no large-cell transformation. A second biopsy was consistent with cutaneous T-cell lymphoma. The T-cell analysis showed cells with CD3 and some CD4 expression and without CD7 or CD8 expression. Approximately $5-10 \%$ of the cells expressed CD30. Most of the cells expressed TCR- $\beta$. No gene rearrangements were noted. In situ hybridization for EBV RNA (EBER) was negative. Flow cytometry of the blood showed minimal blood involvement. The patient was treated with 32 Gy of total body skin electron beam radiation. There was complete clearing of his lesions. Unfortunately, stem cell transplantation was cost-prohibitive.

He returned to his home country after 2 months but re-presented 1 month later with dysphagia, abdominal pain, and a 20-pound weight loss. The skin had many new small tumors $<1 \mathrm{~cm}$ and annular plaques. His mouth was remarkable for two linear white plaques with an erythematous base on the pharynx above the uvula. Ulcerative lesions were present on his edematous epiglottis and left arytenoid. He had a geographic tongue with lack of pili and white-to-yellowish plaque-like lesions along the midline and left lateral anterior dorsal surface (Fig. 1).

Biopsy of the anterior dorsal tongue was filled with atypical lymphocytes extending to the basal layer of the epithelium. There were occasional intraepithelial atypical lymphocytes with irregular nuclei. Immunohistochemistry of the atypical lymphocytes showed $40 \%$ with CD30 positivity. The malignant cells were double negative for both CD4 and CD8, expressed BF-1, and had some labeling for T-cell intracellular antigen, granzyme B, and CD56. This was consistent with epidermotropic cutaneous T-cell lymphoma. Restaging imaging showed lymphomatous involvement in his small intestine (Fig. 2). He received 12 Gy of palliative radiation to his oropharynx, 1 dose of brentuximab vedotin anti-CD30 antibody $(1.8 \mathrm{mg} / \mathrm{kg}$ i.v.), and one cycle of cyclophosphamide-etoposide-vincristine-prednisone (CEOP).

The patient presented to the emergency room with acute abdominal pain 2 weeks after the brentuximab and CEOP administration. His CT scan showed significant progression of 
Emge et al:: A Rare Case of Mycosis Fungoides in the Oral Cavity and Small Intestine Complicated by Perforation

tumor involving the intestine, evidence of obstruction, and intestine perforation with free intraperitoneal air in the region of the small intestine. He underwent emergent abdominal exploration and perforation repair.

After perforation repair, the patient received a second cycle of CEOP. However, he had progression in multiple areas of the skin with tumors. The CEOP was discontinued and gemcitabine $1,000 \mathrm{mg} / \mathrm{m}^{2}$ was started. He ultimately had improvement in functional status and skin tumor burden. After completing two cycles of the gemcitabine nearly 5 months after his oral lesions had initially appeared and 3 months after the perforation, he was admitted to the hospital again with abdominal pain. A second bowel perforation was diagnosed and medically managed by his care team. He was subsequently placed back on a second cycle of brentuximab vedotin after biopsy of the right forearm had shown MF with atypical lymphocytes that were positive for CD3 and CD7, mostly negative for CD4 and CD8, and expressed CD30 in approximately $45 \%$ of lymphocytes. He completed the second cycle at around the time of submission of the manuscript. His prognosis was guarded.

\section{Discussion}

We report the first case of simultaneous involvement of MF in the oral cavity and small intestine. This was the fourth case of intestinal perforation related to MF. However, this case provides insight into the disease process and the complications of lymphomas with GI tract involvement.

The MF disease process has a relatively predictable pattern of three phases: erythematous or eczematous rash, infiltrated plaques, and cutaneous tumors [2]. Ultimately, the MF disease process results in diffuse visceral and lymphatic involvement $[3,4,6]$. This outcome is the hallmark of end-stage disease, which is characterized by atypical lymphocytes that lack the epidermotropism of early-stage MF [7].

Oral cavity involvement of MF is a rare event, a predictor of poor prognosis, and found in late-stage disease. There were only 42 reported cases of oral MF including our patient; most cases of MF in the oral cavity have been described as affecting the tongue and palate, as in our patient [3-6, 8-20].

Extranodal non-Hodgkin lymphoma most commonly occurs in the GI tract, with the small intestine being the most common site of involvement [21]. There have been reports of MF cases throughout the GI tract, including the small intestine (Table 1) [3, 4, 22-43]. Briefly, there have been 67 cases of GI MF in the reported literature. The most common site was the small intestine, as seen in our patient. The majority of cases in the small intestine presented with abdominal pain and ultimately experienced death up to 6 months after presentation with GI MF. Our patient presented similarly, with advanced-stage disease and with abdominal pain shortly after treatment with radiation, brentuximab, and CEOP. He had initial resolution of his skin and oral lesions on gemcitabine, but had disease recurrence with resulting perforation less than 6 months later. His prognosis was guarded.

The complications of GI involvement include hemorrhage, obstruction, and perforation $[6,22,44,45]$. Perforation from lymphoma involvement in the GI tract was a well-known complication, with the majority occurring as the first sign of GI involvement and not as a result of antineoplastic treatment [46-54]. The small intestine was the most common site of 
Emge et al:: A Rare Case of Mycosis Fungoides in the Oral Cavity and Small Intestine Complicated by Perforation

perforation $[53,54]$. Perforation as a result of therapy can occur shortly after treatment, usually within a few weeks, as in our patient $[53,54]$. The risk of perforation from the cytotoxic agent seems to be less than that of the tumor's presence itself, but clinicians should nonetheless be cautious in treating patients with lymphoma in the GI tract.

Our patient initially had intestine perforation 2 weeks after treatment with brentuximab and CEOP. He subsequently had a second perforation after gemcitabine, a nucleoside analogue chemotherapy agent. Although patients with MF are at risk of secondary lymphomas [55], the timing and good response to brentuximab and gemcitabine suggested that the lesions were MF and that the perforations were likely a result of the antineoplastic agents.

To our knowledge, there have been three case reports of intestinal perforation from MF involvement of the small intestine $[22,33,41]$. One of the cases was described in the German-language literature [41]. Of the other patients presented in the two English-language case reports, the first developed perforation with peritonitis approximately 1 year after initial MF treatment [22]. It does not appear that this patient's perforation was related to treatment. However, the second patient presented with perforation of the small intestine after prednisone treatment in a similar fashion to our patient [33].

In conclusion, MF involving both the oral palate and the small bowel is extremely rare. This unique patient had coexistent oral and small bowel lesions apparent on PET scan. The latter was accompanied by abdominal pain and resulted in serious, life-threatening bowel perforations that had been preceded by combination therapy with antibody and multi-agent chemotherapy.

\section{Acknowledgments}

Dr. Duvic is the Blanche Bender Professor in Cancer Research.

\section{Statement of Ethics}

The participant provided written informed consent for use of his case and images per University of Texas MD Anderson Cancer Center (UTMDACC) guidelines. Institutional review board approval was not needed for this study.

\section{Disclosure Statement}

The authors certify that they have no sponsorship or funding arrangements relating to their research. All authors have no disclosures regarding conflicts of interest.

\section{References}

1 Horwitz SM, Olsen EA, Duvic M, Porcu P, Kim YH: Review of the treatment of mycosis fungoides and Sézary syndrome: a stage-based approach. J Natl Compr Canc Netw 2008;6:436-442. 
Emge et al.: A Rare Case of Mycosis Fungoides in the Oral Cavity and Small Intestine Complicated by Perforation

Burgdorf WH: Cutaneous lymphoma; in Freedberg IM, Eisen AZ, Wolff K, Austen KF, Goldsmith LA, Katz SI (eds): Fitzpatrick's Dermatology in General Medicine. New York, McGraw-Hill, 2003.

3 Rappaport H, Thomas LB: Mycosis fungoides: the pathology of extracutaneous involvement. Cancer 1974;34:1198-1229.

Epstein EH Jr, Levin DL, Croft JD Jr, Lutzner MA: Mycosis fungoides: survival, prognostic features, response to therapy, and autopsy findings. Medicine 1972;51:61-72.

Sirois DA, Harwick RD, Vonderheid EC: Oral manifestations of cutaneous T-cell lymphoma. A report of eight cases. Oral Surg Oral Med Oral Pathol 1993;75:700-705.

6 Long JC, Mihm MC: Mycosis fungoides with extracutaneous dissemination: a distinct clinicopathologic entity. Cancer 1974;34:1745-1755. 2008;371:945-957.

Chua MST, Veness MJ: Mycosis fungoides involving the oral cavity. Australas Radiol 2002;46:336-339. palatal biopsy with discussion of diagnostic advantages of plastic embedding. Oral Surg Oral Med Oral Pathol 1984;58:413-419. Evans G, Dalziel K: Mycosis fungoides with oral involvement. A case report and literature review. Int J Oral Maxillofac Surg 1987;16:634-637.

11 Goldsmith SM, Seo BL, de Silva RK, Parachuru P, Rich AM, Seymour GJ: Oral mycosis fungoides: report with immune profile. Oral Surg Oral Med Oral Pathol Oral Radiol 2014;118:e48-e52. de la Fuente EG, Rodriguez-Peralto J, Ortiz P, Barrientos N, Vanaclocha F, Iglesias L: Oral involvement in mycosis fungoides: report of two cases and a literature review. Acta Derm Venereol 2000;80:299-301. Harman M, Akdeniz S, Arslan A, Köyoğlu S: Mycosis fungoides with involvement of the oral cavity. J Eur Acad Dermatol Venereol 1998;10:253-256. Jones D, Vega F, Sarris AH, Medeiros LJ: CD4-CD8-“double-negative” cutaneous T-cell lymphomas share common histologic features and an aggressive clinical course. Am J Surg Pathol 2002;26:225-231. Laskaris GC, Nicolis GD, Capetanakis JP: Mycosis fungoides with oral manifestations. Oral Surg Oral Med Oral Pathol 1978;46:40-42.

16 Luigetti M, Cianfoni A, Scarano E, Laurenti L, Innocenti I, Testani E, Dittoni S, Della Marca G: Mycosis fungoides as a cause of severe obstructive sleep apnea. Intern Med 2011;50:1753-1755. May SA, Jones D, Medeiros LJ, Duvic M, Prieto VG, Lazar AJ: Oral-cutaneous CD4-positive T-cell lymphoma: a study of two patients. Am J Dermatopathol 2007;29:62-67. Postorino M, Pupo L, Provenzano I, Del Principe MI, Buccisano F, Franceschini L, Rizzo M, Nasso D, Meconi F, Onnis I, Vaccarini S, Zizzari A, Anemona L, Mauramati S, Bruno E, Cantonetti M, Amadori S: A case of oral mycosis fungoides successfully treated by combination of alemtuzumab and chemotherapy. Ann Hematol 2016;95:153-154.

19 Wahie S, Lucraft H, Hartley C, Milne D, Prabhu V, Farr P: Oropharyngeal mycosis fungoides. Clin Exp Dermatol 2006;31:821-822. Wright JM, Balciunas BA, Muus JH: Mycosis fungoides with oral manifestations: report of a case and review of the literature. Oral Surg Oral Med Oral Pathol 1981;51:24-31. Gou HF, Zang J, Jiang M, Yang Y, Cao D, Chen XC: Clinical prognostic analysis of 116 patients with primary intestinal non-Hodgkin lymphoma. Med Oncol 2012;29:227-234. Camisa C, Goldstein A: Mycosis fungoides: small-bowel involvement complicated by perforation and peritonitis. Arch Dermatol 1981;117:234-237.

-23 Gómez Venegas ÁA, Vargas Rubio RD: Unusual involvement in mycosis fungoides: duodenal papilla. Rev Esp Enferm Dig 2016;108:513-516.

24 Madsen JA, Tallini G, Glusac EJ, Salem RR, Braverman I, Robert ME: Biliary tract obstruction secondary to mycosis fungoides: a case report. J Clin Gastroenterol 1999;28:56-60. Velagapudi P, Turagam M, Uzoaru I, Graham D: Small bowel obstruction due to mycosis fungoides: an unusual presentation. Am J Med Sci 2011;341:508-509.

-26 Block JB, Edgcomb J, Eisen A, Van Scott EJ: Mycosis fungoides. Natural history and aspects of its relationship to other malignant lymphomas. Am J Med 1963;34:228-235.

27 Ishida M, Mochizuki Y, Saito Y, Fujiyama Y, Hodohara K, Yoshida T, Okabe H: CD8(+) mycosis fungoides with esophageal involvement: a case report. Oncol Lett 2013;5:73-75.

28 Slater DN, Bleehen SS, Beck S: Gastrointestinal complications of mycosis fungoides. J R Soc Med 1984;77:114-119.

29 Chen K, Tanaka M, Miyakawa S: Granulomatous mycosis fungoides with small intestinal involvement and a fatal outcome. Br J Dermatol 1998;138:522-525. 
Redleaf MI, Moran WJ, Gruber B: Mycosis fungoides involving the cervical esophagus. Arch Otolaryngol Head Neck Surg 1993;119:690-693.

-31 Ganz R, Olinger E, Variakojis D, Gordon L: Mycosis fungoides with gastrointestinal involvement. Gastrointest Endosc 1988;34:478-481.

Gottlieb K, Anders K, Kaya H: Obstructive jaundice in a patient with mycosis fungoides metastatic to the pancreas. EUS findings. JOP 2008;9:719-724.

Newton J: Perforation of the small bowel in mycosis fungoides treated with prednisone. Br J Surg 1962;50:105-106.

-34 Branscheid F: Mycosis fungoides des Verdauungskanals ohne Miterkrankung der Haut. Dermatol Wochenschr 1950;121:319-324.

-35 Chéridjian Z: Mycosis fongoïde du pharynx et rhino-pharynx latéral chez un sclérodermique. ORL 1946;8:540-545.

Hood AF, Mark GJ, Hunt JV: Laryngeal mycosis fungoides. Cancer 1979;43:1527-1532.

Kressin J, Schoeder H: Mycosis fungoides der Schleimhaut. Z Hals Nasen Ohrenheilkd 1968;16:261-264.

Engle I, Aakhus T: Intestinal obstruction in mycosis fungoides. Br J Radiology 1965;38:634-636.

Kim OD, Cantave I, Schlesinger PK: Esophageal involvement by cutaneous T-cell lymphoma, mycosis fungoides type: diagnosis by endoscopic biopsy. J Clin Gastroenterol 1990;12:178-182.

Dereure 0, Guilhou J: Mycosis fungoides with predominant periorificial and mucous involvement (in French). Ann Dermatol Venereol 2005;132:877-880. Wiedmann A: Beiträge zur Kenntnis des Granuloma fungoides. Dermatol Wochenschr 1932;XCIV:777. Vasishta R, Kaur S, Singh M, Verma S: Mycosis fungoides - gastric involvement with massive GI bleed. Indian J Gastroenterol 1987;64:239-240.

Tan E, Shao H, Friedman M: Mycosis fungoides of the rectum: case report and review of the literature. J Gastrointest Cancer 2015, Epub ahead of print.

-44 Cyr DP, Geokas MC, Worsley GH: Mycosis fungoides: hematologic findings and terminal course. Arch Dermatol 1966;94:558-573.

45 Cohen MI, Widerlite LW, Schechter GP, Jaffe E, Fischmann AB, Schein PS, Macdonald JS: Gastrointestinal involvement in the Sézary syndrome. Gastroenterology 1977;73:145-149.

46 Loehr WJ, Mujahed Z, Zahn FD, Gray GF, Thorbjarnarson B: Primary lymphoma of the gastrointestinal tract: a review of 100 cases. Ann Surg 1969;170:232-238.

47 Nasr K, Haghighi P, Bakhshandeh K, Haghshenas M: Primary lymphoma of the upper small intestine. Gut 1970;11:673-678. Burman SO, Van Wyk F: Lymphomas of the small intestine and cecum. Ann Surg 1956;143:349-359. Irvine $\mathrm{W}$, Johnstone J: Lymphosarcoma of the small intestine with special reference to perforating tumours. Br J Surg 1955;42:611-618.

50 Naqvi M, Burrows L, Kark A: Lymphoma of the gastrointestinal tract: prognostic guides based on 162 cases. Ann Surg 1969;170:221-231.

-51 Ehrlich AN, Stalder G, Geller W, Sherlock P: Gastrointestinal manifestations of malignant lymphoma. Gastroenterology 1968;54:1115-1121.

52 Sherlock P, Oropeza R: Jejunal perforations in lymphoma after chemotherapy. Arch Intern Med 1962;110:102-107.

53 Vaidya R, Habermann TM, Donohue JH, Ristow KM, Maurer MJ, Macon WR, Colgan JP, Inwards DJ, Ansell SM, Porrata LF, Micallef IN, Johnston PB, Markovic SN, Thompson CA, Nowakowski GS, Witzig TE: Bowel perforation in intestinal lymphoma: incidence and clinical features. Ann Oncol 2013;24:24392443.

54 Spectre G, Libster D, Grisariu S, Da'as N, Yehuda DB, Gimmon Z, Paltiel O: Bleeding, obstruction, and perforation in a series of patients with aggressive gastric lymphoma treated with primary chemotherapy. Ann Surg Oncol 2006;13:1372-1378.

55 Huang KP, Weinstock MA, Clarke CA, McMillan A, Hoppe RT, Kim YH: Second lymphomas and other malignant neoplasms in patients with mycosis fungoides and Sézary syndrome: evidence from population-based and clinical cohorts. Arch Dermatol 2007;143:45-50. 


\section{Case Reports in Dermatology}
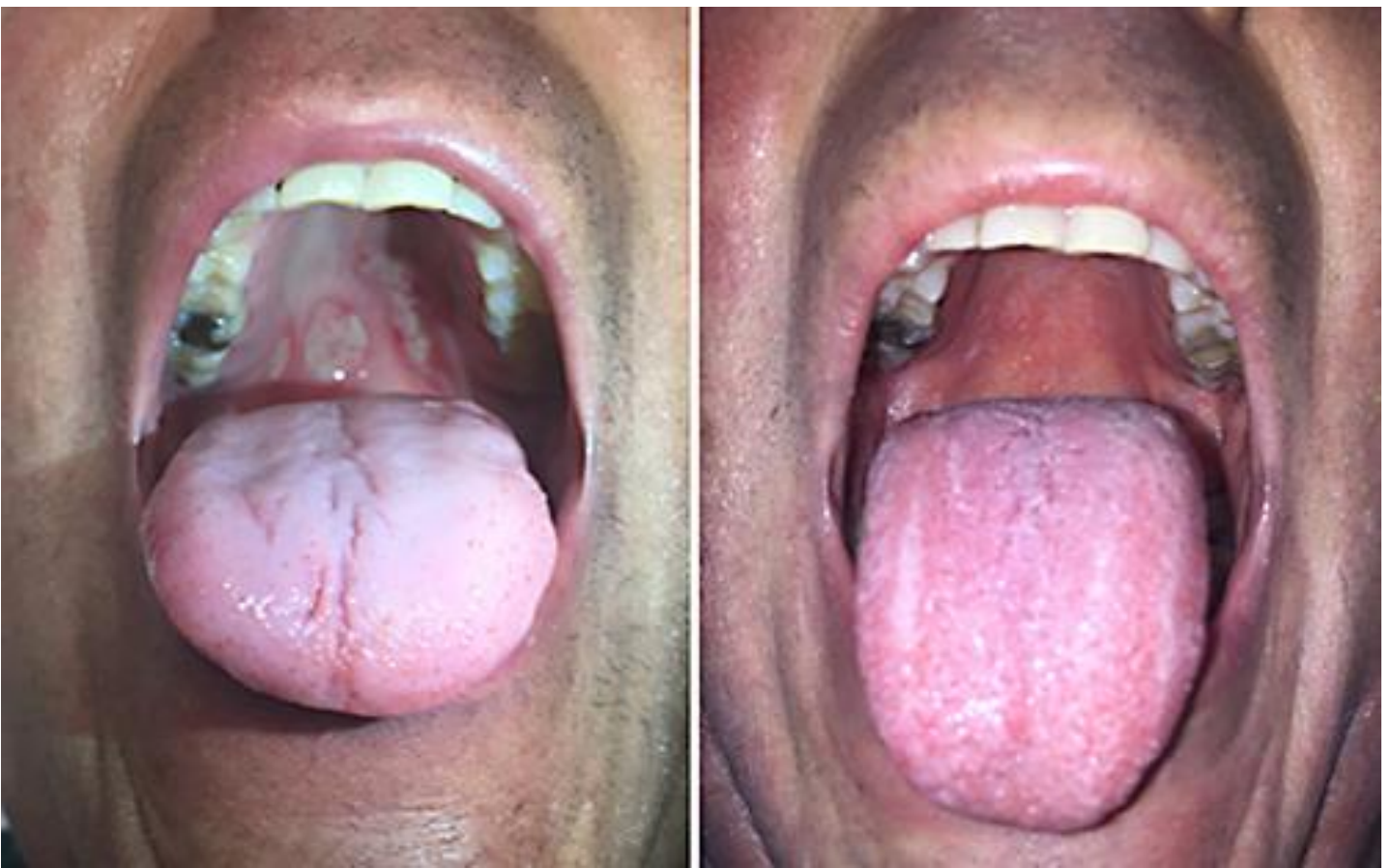

Fig. 1. Lesions of the tongue and palate before (left) and after (right) treatment with palliative radiation to the oropharynx. 


\section{Case Reports in Dermatology}

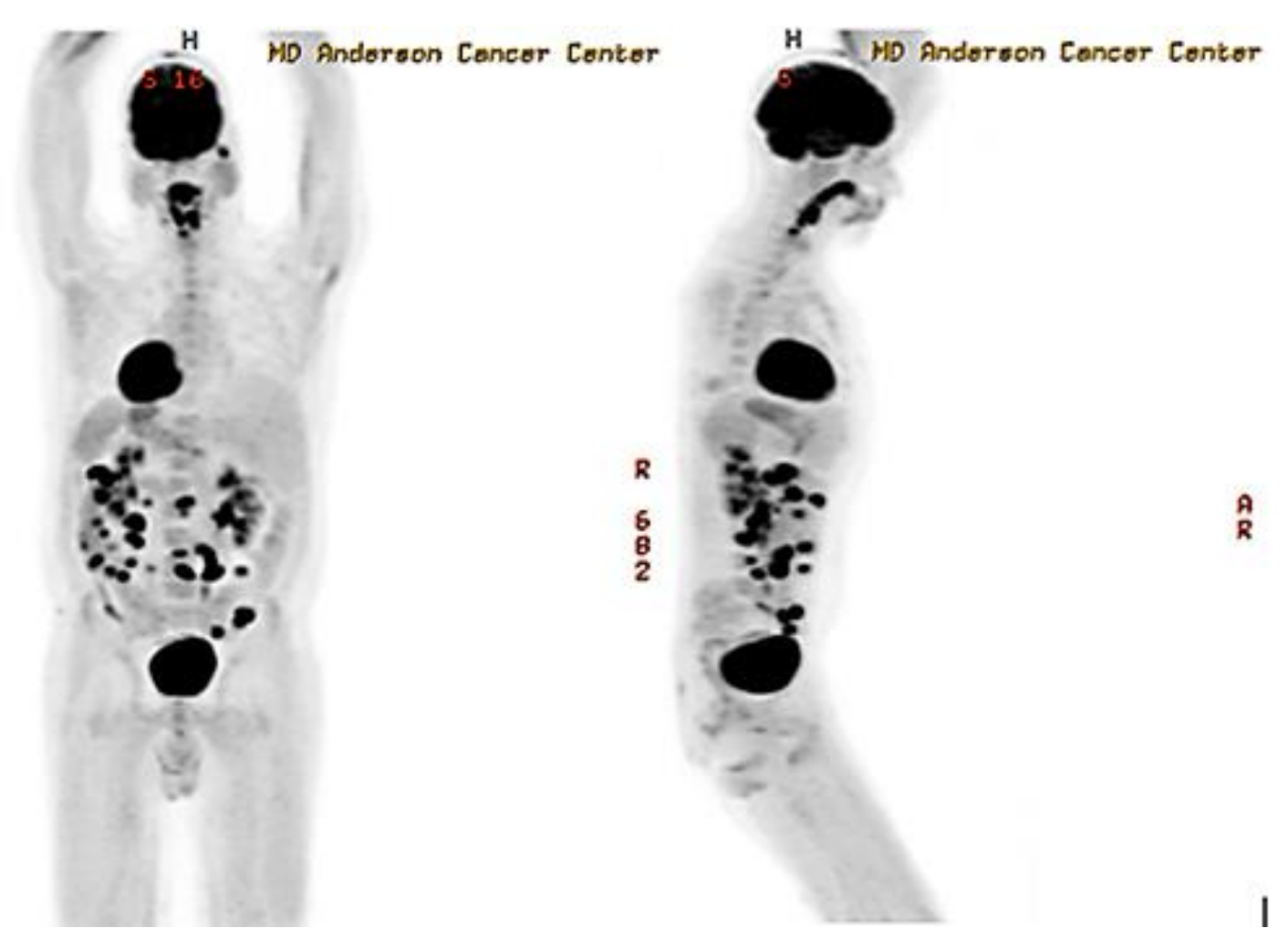

(C) 2016 The Author(s). Published by S. Karger AG, Basel www.karger.com/cde

Emge et al:: A Rare Case of Mycosis Fungoides in the Oral Cavity and Small Intestine Complicated by Perforation

Fig. 2. Two views of restaging imaging showing increased fludeoxyglucose tracer uptake in the small intestine. 
Table 1. Summary of reported cases of mycosis fungoides in the gastrointestinal tract

\begin{tabular}{|c|c|c|c|c|c|c|c|c|c|c|}
\hline \multirow{2}{*}{$\begin{array}{l}\text { Reference } \\
\text { (first author) }\end{array}$} & \multirow{2}{*}{$\begin{array}{l}\text { Cases } \\
\text { reported, } \\
\mathrm{n}\end{array}$} & \multicolumn{5}{|c|}{ Site of involvement } & \multirow[t]{2}{*}{ Presentation } & \multirow[t]{2}{*}{ Complication } & \multirow[t]{2}{*}{ Treatment } & \multirow[t]{2}{*}{ Outcome } \\
\hline & & $\begin{array}{l}\text { esoph- } \\
\text { agus }\end{array}$ & ston & $\begin{array}{l}\text { lachsmall } \\
\text { intestine }\end{array}$ & $\begin{array}{l}\text { large } \\
\text { intestine }\end{array}$ & $\begin{array}{l}\text { rectum/ } \\
\text { anus }\end{array}$ & & & & \\
\hline Long [6] & 4 & 2 & 2 & - & - & - & - & hemorrhage & - & $\begin{array}{l}\text { death (autopsy } \\
\text { series) }\end{array}$ \\
\hline Epstein [4] & 30 & 7 & 7 & 13 & 2 & 1 & - & - & - & $\begin{array}{l}\text { death (autopsy } \\
\text { series) }\end{array}$ \\
\hline $\begin{array}{l}\text { Rappaport } \\
\text { [3] }\end{array}$ & 11 & 1 & 4 & & $6^{a}$ & - & - & - & - & $\begin{array}{l}\text { death (autopsy } \\
\text { series) }\end{array}$ \\
\hline Ganz [31] & 1 & 1 & 1 & 1 & 1 & - & diarrhea & $\begin{array}{l}\text { gastric ulcer, } \\
\text { colonic ulcers }\end{array}$ & CT & $\begin{array}{l}\text { death after } \\
4 \text { months }\end{array}$ \\
\hline Ishida [27] & 1 & 1 & - & - & - & - & dysphagia & $\begin{array}{l}\text { esophageal } \\
\text { ulcer }\end{array}$ & $\begin{array}{l}\mathrm{CT}, \\
\text { radiation }\end{array}$ & death \\
\hline Kim [39] & 1 & 1 & - & - & - & - & $\begin{array}{l}\text { dysphagia, } \\
\text { odynophagia, } \\
\text { weight loss }\end{array}$ & - & - & - \\
\hline $\begin{array}{l}\text { Chéridjian } \\
\text { [35] }\end{array}$ & $1^{\mathrm{b}}$ & $1^{\mathrm{b}}$ & - & - & & - & odynophagia & - & - & - \\
\hline $\begin{array}{l}\text { Kressin [37] } \\
\text { (case 1) }\end{array}$ & 1 & 1 & - & - & - & - & dysphagia & - & - & - \\
\hline $\begin{array}{l}\text { Kressin [37] } \\
\text { (case 2) }\end{array}$ & 1 & 1 & - & - & - & - & - & - & - & - \\
\hline Hood [36] & 1 & 1 & - & - & - & - & dysphagia & $\begin{array}{l}\text { ulcerations } \\
\text { with Candida }\end{array}$ & $\begin{array}{l}\text { not } \\
\text { specified }\end{array}$ & $\begin{array}{l}\text { death } 4 \text { years } \\
\text { after mycosis } \\
\text { fungoides onset }\end{array}$ \\
\hline Dereure [40] & 1 & 1 & - & - & - & - & dysphagia & $\begin{array}{l}\text { ulcerated } \\
\text { nodules }\end{array}$ & CT & death \\
\hline Redleaf [30] & 1 & 1 & - & - & - & - & $\begin{array}{l}\text { dysphagia, } \\
\text { hoarseness }\end{array}$ & - & radiation & - \\
\hline Vasishta [42] & 1 & - & 1 & - & - & - & diarrhea & $\begin{array}{l}\text { upper } \\
\text { gastrointestinal } \\
\text { bleed, ileus }\end{array}$ & - & $\begin{array}{l}\text { death after } \\
2 \text { days }\end{array}$ \\
\hline $\begin{array}{l}\text { Wiedmann } \\
\text { [41] }\end{array}$ & 1 & - & 1 & - & - & - & $\begin{array}{l}\text { abdominal } \\
\text { pain }\end{array}$ & perforation & - & - \\
\hline $\begin{array}{l}\text { Slater [28] } \\
\text { (case 1) }\end{array}$ & 1 & - & 1 & - & - & - & $\begin{array}{l}\text { abdominal } \\
\text { pain }\end{array}$ & gastric ulcer & - & - \\
\hline $\begin{array}{l}\text { Slater [28] } \\
\text { (case 2) }\end{array}$ & 1 & - & - & 1 & - & - & $\begin{array}{l}\text { weight loss, } \\
\text { diarrhea }\end{array}$ & - & CT & $\begin{array}{l}\text { death after } \\
6 \text { cycles of CT }\end{array}$ \\
\hline Chen [29] & 1 & - & - & 1 & - & - & abdominal pain & perforation & - & $\begin{array}{l}\text { death after } \\
2 \text { months }\end{array}$ \\
\hline Camisa [22] & 1 & - & - & 1 & - & - & abdominal pain & perforation & $\begin{array}{l}\text { laparotomy, } \\
\text { resection }\end{array}$ & $\begin{array}{l}\text { death after } \\
30 \text { days }\end{array}$ \\
\hline $\begin{array}{l}\text { Velagapudi } \\
\text { [25] }\end{array}$ & 1 & - & - & 1 & - & - & $\begin{array}{l}\text { abdominal pain, } \\
\text { emesis, } \\
\text { constipation }\end{array}$ & $\begin{array}{l}\text { small intestine } \\
\text { obstruction }\end{array}$ & $\begin{array}{l}\text { laparotomy, } \\
\text { resection }\end{array}$ & $\begin{array}{l}\text { death after } \\
6 \text { months }\end{array}$ \\
\hline Newton [33] & 1 & - & - & 1 & - & - & abdominal pain & perforation & $\begin{array}{l}\text { laparotomy, } \\
\text { cortisone }\end{array}$ & $\begin{array}{l}\text { death after } \\
5 \text { days }\end{array}$ \\
\hline $\begin{array}{l}\text { Gómez } \\
\text { Venegas [23] }\end{array}$ & 1 & - & - & 1 & - & - & fever, fatigue & fistula & - & $\begin{array}{l}\text { death after } \\
20 \text { days }\end{array}$ \\
\hline Engle [38] & 1 & - & - & 1 & - & - & $\begin{array}{l}\text { abdominal pain, } \\
\text { nausea, vomiting }\end{array}$ & $\begin{array}{l}\text { stricture of } \\
\text { colon }\end{array}$ & $\begin{array}{l}\mathrm{CT}, \\
\text { radiation }\end{array}$ & $\begin{array}{l}\text { death after } \\
4 \text { months }\end{array}$ \\
\hline $\begin{array}{l}\text { Branscheid } \\
{[34]}\end{array}$ & 1 & - & - & - & 1 & - & - & - & - & - \\
\hline Tan [43] & 1 & - & - & - & - & 1 & $\begin{array}{l}\text { abdominal pain, } \\
\text { constipation, } \\
\text { diarrhea }\end{array}$ & - & radiation & - \\
\hline $\begin{array}{l}\text { Current } \\
\text { report }\end{array}$ & 1 & - & - & 1 & - & - & abdominal pain & $\begin{array}{l}\text { perforation, } \\
\text { obstruction }\end{array}$ & $\begin{array}{l}\text { laparotomy, } \\
\text { CT }\end{array}$ & $\begin{array}{l}\text { subsequent } \\
\text { recurrent } \\
\text { disease and } \\
\text { perforation }\end{array}$ \\
\hline Total & $67^{c}$ & 19 & 17 & 22 & 4 & 2 & & & & \\
\hline
\end{tabular}

CT, chemotherapy. a Not specified as to the site of lesion (small versus large intestine), so excluded from final tallies in "Total" row. b Probable case of mycosis fungoides. ${ }^{c}$ Grand total of gastrointestinal mycosis fungoides cases. 